\title{
Intersections
}

Canadian Journal of Music

Revue canadienne de musique

\section{Carl Wilson. 2007. Let's Talk About Love: A Journey to the End of Taste. New York: Continuum. 164 pp. ISBN 13: 978-0-8264-2788-5 (paperback).}

\section{Christopher Cwynar}

Volume 28, numéro 1, 2007

URI : https://id.erudit.org/iderudit/019300ar

DOI : https://doi.org/10.7202/019300ar

Aller au sommaire du numéro

Éditeur(s)

Canadian University Music Society / Société de musique des universités canadiennes

ISSN

1911-0146 (imprimé)

1918-512X (numérique)

Découvrir la revue

Citer ce compte rendu

Cwynar, C. (2007). Compte rendu de [Carl Wilson. 2007. Let's Talk About Love: A

Journey to the End of Taste. New York: Continuum. 164 pp. ISBN 13:

978-0-8264-2788-5 (paperback).] Intersections, 28(1), 199-201.

https://doi.org/10.7202/019300ar

Tous droits réservés (C) Canadian University Music Society / Société de musique des universités canadiennes, 2007
Ce document est protégé par la loi sur le droit d'auteur. L’utilisation des services d'Érudit (y compris la reproduction) est assujettie à sa politique d'utilisation que vous pouvez consulter en ligne.

https://apropos.erudit.org/fr/usagers/politique-dutilisation/ 
Rouget, Gilbert. 2004. «L'efficacité musicale : musiquer pour survivre. Le cas des Pygmées ». L'Homme 171-172: <http://lhomme.revues.org/document1270. html>.

Sandwell, Bernard Keble. 1907. Musical Red Book of Montreal (1895-1907). Montréal : F.A. Veitch.

Small, Christopher. 1998. Musicking: The Meanings of Performing and Listening. Hanover : University Press of New England.

Spier, Susan. 1986. «The Dubois String Quartet 1910-1938: Its Role in Montreal Music History ». Mémoire de maîtrise, Université de Montréal.

Thirlwall, Stephen Lawrence. 1992. "Musical Landscape: A Definition and a Case Study of Musical Landscape in its Contribution to the Development of Quebecois Identity ». Mémoire de maîtrise, Carleton University.

Vaudrin, Marie-Claude. 2004. La musique techno, ou, Le retour de Dionysos : je rave, tu raves, nous rêvons. Paris : L'Harmattan.

\section{DISCOGRAPHIE}

Keillor, Elaine. 2000. Canadians at the keyboard. Livret et disque compact. Carleton Sound, CSCD-1008.

Claudine Caron

Carl Wilson. 2007. Let's Talk About Love: A Journey to the End of Taste. New York: Continuum. 164 pp. ISBN 13: 978-0-8264-2788-5 (paperback).

Carl Wilson's treatment of Céline Dion's Let's Talk About Love marks a significant departure in Continuum's popular $331 / 3$ series of books devoted to individual albums. The selection of a work by the resolutely mainstream Dion initially seems curious amidst the array of cult classics and canonical pop records that have previously been addressed in the series. In fact, the somewhat tongue-incheek subtitle to Wilson's book- "A Journey to the End of Taste"-reveals that this is not a conventional piece of music criticism. Where participants in the series often attempt to justify their affection for their subjects, Wilson's contribution purports to evaluate the author's problematic relationship with the artist behind his chosen text so that he might better understand the nature of his own tastes. This refreshingly unorthodox approach yields numerous insights into the nature of taste and the social utility of culture in the twenty-first century.

The most crucial of these insights pertain to the social function of taste and the interplay between ethical and aesthetic factors in the formation of cultural judgments. Wilson does not actually reach the "end of taste"-nor does he appear to believe in the "end" of things like taste or history-but he does explore our complex relationship with taste in this ostensibly post-taste era of increasing cultural fragmentation and relativism. Investigating his personal difficulties with Dion and her music, Wilson locates the crux of the issue in the mainstream. He notes that "middlebrow is the new lowbrow-mainstream the 
only taste for which you still have to say you're sorry" (p. 86). This observation comes at the conclusion of the chapter on the nature of aesthetic taste and it underscores the connections between taste and cultural capital. In these concise chapters, Wilson breaks down the ethics behind ostensibly aesthetic judgments and demonstrates how they serve their arbiters in the pursuit of social distinction. From the ironic reclamation of the lowbrow, to the philosophical basis for accepted aesthetic principles in highbrow culture, Wilson adroitly guides the reader through a number of complicated areas, effectively mixing accessible theoretical discussions with pertinent personal anecdotes and thoughtful observations. Wilson's self-awareness is an essential virtue here; his willingness to unflinchingly evaluate his own cultural assumptions and taste preferences implicitly encourages the reader to do the same.

Wilson's analysis of his relationship with Dion's music also produces incisive discussions of many of the most vital issues in the study of popular music, including race, class, globalization, authenticity, and virtuosity. Wilson addresses the manner in which Dion's Quebecois origins have subtly shaded her as an "other" in the popular music industry, noting that "Céline the Québécoise falls off the color-coded map of American music, which is part of why global constituencies embrace her" (p. 52). In the course of a fascinating history of schmaltz, Wilson proceeds to situate Dion in a tradition of schmaltz-laden ethnic outsiders including Tony Bennett and Frank Sinatra. For Wilson, however, Dion outdoes her predecessors with her brand of "hyperschmaltz, a frankengenre of sentimental intensity" (p. 60). This hyperschmaltz-with its utterly earnest public displays of excessive sentiment-is an irredeemably middlebrow quality that goes some way towards explaining the critical disdain that Dion tends to provoke.

Yet, Wilson is also aware that the millions of ardent Dion fans care little for such debates or distinctions as they dwell comfortably in the mainstream. This awareness shapes his attempt to review an imagined reissue of Let's Talk About Love for an imagined magazine assignment. Wilson wants to see how his taste experiment might influence his criticism and the position he assumes relative to his subject (he confesses that he seems to have "converted Céline from a guilty displeasure into a classic guilty pleasure, a category I thought I'd thrown away long ago" (p. 136)). The result is a sublime piece of criticism in which Wilson skillfully weaves together autobiographical elements, pop culture acumen, and aesthetic analysis in eleven pages of sprightly prose. Coming near the end of the book, the review provides Wilson with an ideal opportunity to apply the insights gleaned from the preceding discussions to the title text. When Wilson acknowledges that "people need sentimental songs to marry, mourn, and break up to" (p. 147), he approaches the sort of "subcultural translation" (p. 148) that would make his experiment an obvious success. When he subsequently makes the trenchant observation that much of the music that is critically acclaimed at present is primarily "good music to listen to while making aesthetic judgments" (p.157), the reader can sense that Wilson is closer still to understanding his own tastes and their motivations. 
Ultimately, however, the experiment's success is not to be measured in the completion of the translation, but in the effort expended in the attempt and the insights gleaned during the process. According to Wilson, what matters in the end is that he gave the record a "sympathetic listen" (p. 155). He observes that "looking at her (Céline's) seemingly mundane music has focused me on another set of virtues-not so much the fidelity and devotion she sings about, but the persistence and flexibility it takes to translate between her terms and mine" (p. 151). This is a useful lesson, and Wilson concludes by exhorting his readers to engage in similar taste experiments so that they might learn it on their own terms.

Towards the end of the book Wilson observes that most contemporary music criticism is merely an exercise in taste justification. He asks, "what would criticism be like if it were not foremost trying to persuade people to find the same things great? If it weren't about making cases for things?" (p. 156). Let's Talk About Love is Wilson's compelling answer to that question, and its insights will inspire the active reader to reconsider the nature of his or her own relationship with art and culture.

Christopher CWynar 